\title{
Excellence, Innovation and Academic Free- dom in University Policy in Iceland
}

\author{
Ingólfur Ásgeir Jóhannesson, Ph.D., prófessor, Menntavísindasvið Há- \\ skóla Íslands og kennaradeild Háskólans á Akureyri
}

\begin{abstract}
This article analyzes three reports on higher education, research and innovation policy in Iceland by using a Foucauldian discourse analysis approach. The reports were released in 2009 and 2012, emphasizing the simplification of the research and innovation system in Iceland. While on the surface the reports include practical recommendations, the study reveals a strong moral stance in the reports which express concerns that too many universities and two small institutions spread efforts too widely. Suggestions to reorganize the system tend to be presented by simply stating that it is important to do so, but sometimes such assertions are also interwoven with arguments for larger and more powerful universities and research institutions. There is a focus in the reports on innovation and the creation of economic value. Research, science, and innovation are firmly combined with the goal of economic growth. There is the undertone that it is relatively easy to define what is good research or even quality research; and the chief criterion seems to be that good research is research that is useful for business and industry. Academic freedom, on the other hand, is rarely discussed in the reports.
\end{abstract}

Keywords: Discourse, academic freedom, public role of universities, university and the economy, higher education. 


\section{Introduction}

In this article I focus on the discourse about the relationship between the universities and the economy in Iceland. For this purpose, I examined two reports from 2009 and one from 2012 that deal with issues of efficiency and competitiveness in higher education to see how they use concepts of quality and excellence as well as related concepts. I also considered the potential consequences for academic freedom resulting from demands placed upon the universities with regard to emphasis on innovation.

\section{Background}

Iceland is an island of 100 thousand square kilometers, inhabited by 320 thousand people (2012). The history of modern Iceland is very brief, and so is the history of Icelandic universities. Its largest university, University of Iceland with almost 14,000 students (2011), is also its oldest, established in 1911 with four faculties. Today the University of Iceland is organized into five schools with 25 faculties divided into about 360 study programs in social sciences, humanities, health sciences, education, and natural sciences and technology (University of Iceland, n.d.). There are six other universities and colleges with a total of about 130 study programs in social sciences, health sciences, natural sciences, agricultural sciences, and arts (numbers as of 2009). Altogether, universities in Iceland had about 19,000 students enrolled in 2011. Universities number two and three in size are Reykjavík University and the University of Akureyri. The other four are the Academy of the Arts, Bifröst University, the Agricultural University of Iceland, and Hólar University College. ${ }^{1}$

Prior to 1987 when the University of Akureyri was established, there were only two universities; University of Iceland and Iceland University of Education, which has now merged with the University of Iceland as the base for its School of Education. Since 1987, there has been significant growth in the Icelandic university system: more universities, degrees in new disciplines and interdisciplinary programs, more master's programs established, the foundation of private universities, and, most recently, doctoral education has been developed. The higher education system in Iceland also grew fast in number of students, for example from 8,100 students in 1997 to 19,099 in 2011 (Statistics Iceland, 2012). Indeed, "higher education in Iceland has grown and diversified more quickly and more recently than almost any other OECD country ..." (Ministry of Education, Science, and Culture, 2009a, p. 3).

Various legislative changes relating to the structure of the universities have occurred since the final years of the 20th century. These include changes in the funding system for the universities, which are for the most part state-funded, now through contracts based on student numbers; furthermore, higher education legislation now stipulates that universities are to adopt a quality assurance system (Lög um háskóla no 63/2006, article 11). In tact with this legislation, Icelandic universities were accredited by the Ministry of education, science and culture in 2007-2008. Further, Icelandic universities have adopted measures that have been called the Bologna Process (see, for example, Guðrún Geirsdóttir and Ingólfur Ásgeir Jóhannesson, 2010). The Bologna Process, first formally adopted 


\section{STJÓRNMÁL \& \\ STJÓRNSÝSLA}

in 2007, uses tools, such as the mandatory definition of learning outcomes, to enhance quality in a systematic way. It also facilitates mobility of students, faculty, staff, and graduates (Auglýsing um útgáfu viðmiða um æðri menntun og prófgráður no 530/2011).

Regardless of the legislative changes and the growth of the system, the Icelandic higher education system is still reported to be behind the neighboring countries, as an international Expert Panel on higher education pointed out: "Investment in tertiary education is below the OECD average, however, despite the enormous growth in the number of university graduates over the past 11 years $(63 \%$, compared to the OECD average of 15\%)" (Ministry of Education, Science, and Culture, 2009a, p. 3).

The author was an active participant in the accreditation process in one university (University of Akureyri) and has been active in the induction of the Bologna process in two universities (University of Akureyri and University of Iceland); thus involved in these changes on a day-to-day basis. Yet being critical of the efficiency demands to knowledge, which I participated in inducing, made me want to scrutinize some of the documents written in the atmosphere of accountability and under what Páll Skúlason (2008), former rector of the University of Iceland, calls the dominance of the market thinking and the common view of capitalism and Marxism that the economy is the driving force of everything, including what takes place in universities. My other preconceptions of what to find include that I expected the metaphor of knowledge as production, as well as I did not much expect to see a discussion of gender or other equality issues, but a focus on competition as a mother of all battles to be won.

I was also curious to see how academic freedom would be treated in the reports. The basic definition in Encyclopadia Britannica (N.d.), adopted by the Presidents of Icelandic Universities (2005)_ “the freedom of teachers and students to teach, study, and pursue knowledge and research without unreasonable interference or restriction from law, institutional regulations, or public pressure" - is a rather practical one without much ideological stance about critical thinking or the ultimacy of the thought of intellectual thinker, as in my romantic view of academic freedom. Former of faculty of education at the University of Akureyri, Guðmundur Heiðar Frímannsson (2012) deals also with academic freedom as a practical issue.

\section{Research approach}

The approach used here to understanding the discourse is derived from the Michel Foucault (1979a, 1979b) whose main objective is to search for the rules that historically and politically determine what can be said and what cannot be said, and where and how. The term discursive theme refers to words and ideas, behavior and practices, that are recurrent in the discourse (Jóhannesson, 2006, 2010). The particular notion of historically and politically constructed legitimating principles used here is derived from Pierre Bourdieu (e.g., 1988). Using the concept of legitimating principles helps identify discursive themes and practices that fall into patterns that are durable in character. Importantly for the task undertaken in the article, the participants in certain discourse consciously and unconsciously employ the various ideas and practices (Bourdieu, 1988; Jóhannes- 
son, 2010). This means that at the same time as we, the bulk of university people, are likely to denounce suggestions we dislike in the reports we are also likely to adopt some of the stances outlined and, more importantly, take those we do not like seriously enough to talk about and against them. Not only because we are forced to; but rather has the continuing discussion regarding higher education issues tended to be framed around some of recommendations of the reports.

The actual method used here to perform the study is best described in several steps of selecting issues and documents and analyzing them (e.g., Jóhannesson, 2006, 2010; Sharp \& Richardson, 2001). These steps are: (1) identifying the issue (this has already been described), (2) finding documents (or other data, if applicable) to analyze, (3) studying them thoroughly for the discursive themes that can be identified, (4) scrutinizing the patterns in which the discursive themes fall and assessing their durability, as well as the ways in which they refer to existing principles of legitimation in the discourse or shape new such principles, and, (5) if possible, placing these principles in the historical conjuncture of discourses and practices. While at this stage, it is important to consider not only the larger context of legitimating principles but the consequences of the availability of positions we can resist or adopt. Lastly, step 6 involves writing a report; an earlier draft written for a conference served that purpose in this case.

\subsection{Data}

I have selected as data two examples_-or cases_-from the discourse. In May 2009, the Ministry of Education, Science, and Culture released two reports on university policy. The first was written by a five-member panel of foreign experts, entitled Education, Research and Innovation policy. A new direction for Iceland (Ministry of Education, Science, and Culture, 2009a). Simultaneously another report was written by a ten-member Icelandic task force (Ministry of Education, Science, and Culture, 2009b). The Expert Panel and the task force, both appointed by the minister of education, culture, and science, worked independently of each other, but had coordinating meetings. For the purposes of this article, they are analyzed here as one set of reports because the committees were appointed and the reports released simultaneously in the face of Iceland's serious financial crisis after the collapse of the bank system in October 2008.

Each of the two reports slightly exceeds 20 pages. They were accompanied by a two page press release from the ministry and a four page follow-up report by a 16-member focus group appointed by the minister of education, science, and culture. Below, these documents are referred to as the Expert Panel report (Ministry of Education, Science, and Culture, 2009a), the Task Force report (Ministry of Education, Science, and Culture, 2009b), the Press Release (Ministry of Education, Science, and Culture, 2009c), and the Follow-up report (Ministry of Education, Science, and Culture, 2009d). The actual analysis is limited to the Expert Panel and Task Force reports. (Hereafter I use the abbreviation MESC in the references.)

My interest in studying the 2009 reports was awakened almost immediately after they 


\section{STJÓRNMÁL \& \\ STJÓRNSÝSLA}

were released in the spring that year. I became interested in how key terms, such as efficiency, competitiveness, excellence, quality, and academic freedom, were used in these reports. This set of reports also focused on the relationship between education and economy, a recurrent issue in the discourse on education. In this way, the 2009 reports almost chose themselves for such an analysis.

The Science and Technology Policy Council decided in 2011 to compose a report on how it would be possible to simplify the research and innovation system with quality and excellence in mind (Starfshópur Vísinda- og tækninefndar VTR, 2012, p. 9). It nominated a five-member working group, who in cooperation with five others, released what is called a draft report in March 2012, entitled Einföldun á vísinda- og nýsköpunarkerfinu, or Simplifying the research and innovation system (hereafter the Simplifying-report, referred to as Starfshópur, 2012) ${ }^{2}$. The Simplifying report is in two parts; Part A which is a proposal about how to reform ("simplify") the science and innovation system (23 pages), and Part B which describes science and innovation in Iceland by pulling together information about policy, legislation, universities, research institutions, firms, and others that conduct any kind of research, financing and support systems of science and innovation, international cooperation, and quality assessment systems. There are also two short attachments (Viðaukar) about budgeting. This report reawakened my interest in analyzing the 2009 reports.

The analysis of the Simplifying report is mostly limited to Part A. Part B is less normative, and as it mainly conveys information it is not comparable to the 2009 reports in a similar manner as Part A. The arguments for selecting the Simplifying report for the analysis are at least fourfold: it is one of the most recent documents that deal with education focusing on efficiency; its focus is on "simplifying" the research and innovation system; it ties together research and innovation, for instance in the title; and, lastly, it defines its agenda as suggesting how to utilize the ideas in the 2009 reports. Thus there is a built-in link between the two cases. The Expert Panel and the Task Force reports from 2009 and Part A of the Simplifying report are also of a similar length each which helps when comparing how often particular terms occur.

The reports I selected as examples are, in my opinion, fairly representative of university policy discourse. Yet they are not meant to cover all there is about the policy on higher education and research. Thus, documents such as the policy of the University of Iceland from 2006, which maintains that it would serve Icelandic society to bring the university into the group of the 100 best higher education institutions in the world (University of Iceland, 2006), and the science and technology policy for Iceland 2010-2012 (Prime Minister's Office \& Science and Technology Policy Council, 2010) are among other documents worth pursuing in this context. Reading the two documents suggested to me that the reports analyzed here are indeed valid examples of the discourse, although different words and viewpoints on particular things (such as a policy on the ethics as intervowen into all programs at the University of Iceland) characterize each document. $^{3}$ 


\section{STJÓRNSÝSLA}

\subsection{Analysis}

I searched the reports for the discursive themes in order to identify the ways in which ideas and practices are legitimated in the discourse. The themes create discursive patterns that legitimate the use of certain terms rather than others. These patterns or principles constitute what is appropriate to state at certain moments or in certain places (Jóhannesson, 2010). In this case, I searched for the use of selected words, using the search engines in Adobe or Word. The number of occurrences is, simultaneously, informative as to what the reports say, and insufficient, since it does not explain how these terms are used. Therefore, a closer reading was performed to investigate the context and to identify terms that appear less often or not at all, review interesting statements, and gain an insight into each report as an entity.

I read and word-searched the 2009 reports, first almost immediately after their release, but did not complete these procedures until after I had read the 2012 report. I began by searching for the terms efficiency, innovation, governance, private, public, excellence, quality, competitiveness, change, and academic freedom in the Expert Panel report (see Table 1 below). Later I added international, mobility, and exchange to the search. In the Task Force report, written in Icelandic, I chose corresponding words (sometimes more than one word in Icelandic for a term in English): Nyiting, samlegd, skilvirkni, rekstrarform, einka-, opinber, árangur, öndvegis-, gaði, samkeppni, breytingar, alpjódlegur, hreyfanleiki, and akademisk.t frelsi, but with no word corresponding to exchange. I later added prioritization to the search in the Expert Panel report and verkaskipting (division of tasks) to the search in the Task Force report. Still later, while reading the report from 2012, I added einföldun and verdmatasköpun (simplification, creation of economic value) to the search. There is no absolute certainty of the correspondence between terms in English and Icelandic, but potential differences are discussed if I think they matter. Further, the terms are not always used in exactly the same manner, and in some instances there are variations in word groups (e.g., noun, verb, adjective) that may matter.

The 2012 report underwent a similar scrutiny as the 2009 reports, but with a focus on whether the discourse in the 2009 reports was continued. I began by investigating if and how the underlying patterns of legitimation in the 2009 reports remained intact. I then counted the terms I had counted in the 2009 reports, as well as the new terms which, in the first readings of the Simplifying report, had appeared as discursive themes (see Table 1). As noted above, this led to rereadings of the 2009 reports in order to examine whether variations in the discursive themes constituted changes in the patterns of legitimation. In this article, I refer to legitimating patterns rather than principles, since I am uncertain whether they can be considered durable or not, and thus not "principles" in a strict sense of the concept of historically and politically constructed legitimating principles.

The final part of the analysis was an examination of how the discursive themes and legitimating patterns can be viewed in the historical conjuncture of discourses before and after the bank system collapse in October 2008, not least to identify potential contradictions or silences regarding issues, events, or positions I believed should be relevant enough to be mentioned in such reports. 


\section{STJÓRNMÁL \\ STJÓRNSÝSLA}

\section{Findings}

\subsection{Discursive themes in the $\mathbf{2 0 0 9}$ reports}

In Table 1 I have pulled together the results of the word search in the 2009 and 2012 reports. This is followed by identifying eight sets of discursive themes in the 2009 reports and a discussion of the patterns of legitimation in the 2009 reports.

\subsubsection{Efficiency and prioritization}

Efficiency was the first word I searched for. It appears 11 times if the adjective efficient is added in the Expert Panel report, and the three corresponding Icelandic nouns, nýting, samlegd, and skilvirkni, appear 12 times in the Task Force report. The importance, however, of the terms is greater than the number of occurrences might reflect. The Expert Panel emphasized that "cuts" in the education sector "should not prevent efforts to improve efficiency" (MESC, 2009a, p. 11), and that it would be important "in the short run to increase the efficiency in the system ...". The Task Force focused on the importance of a "simple, efficient, and holistic institutional framework for higher education in the country ... especially if many universities offer programs in the same disciplines ..." (MESC, 2009b, p. 8). ${ }^{4}$ The disbelief in that having many small universities is widespread; for instance, the editor of Fréttablaðið, one Iceland's two leading newspapers, wrote in May 2010: "It is obvious that a society with just about 300 thousand people is not capable of running seven universities" (Stefánsdóttir, 2010; cited in Guðmundsson, 2011, p. 662). This is, somehow, a moral stance, which I also wish to pinpoint as the size matters-pattern in the discourse.

In mid-year 2008 the two largest universities, that is, University of Iceland and Iceland University of Education, had been merged. Nevertheless, the Expert Panel argues that "moves towards the creation of an effective and coherent system of higher education and research have not been sufficient" (MESC, 2009a, p. 9). This large merger may indeed have influenced the call for more widespread consolidation, not because of any assessment of its success, but simply by the example.

Prioritization as a noun or verb appears 19 times in the Expert Panel report and the word focus 18 times. In one of the headings this is expressed as "intelligent prioritization" (MESC, 2009a, p. 13). The Expert Panel worries that non-competitive "block funding ... makes it difficult to steer ..." and argues that "sufficient instruments to make effective prioritization happen" are needed (MESC, 2009a, p. 13). The Expert Panel goes on to discuss "promising areas for the future" and suggests that prioritization might be „easier if it does not entail budget shifts and even discontinuation of existing programs and initiatives" (MESC, 2009a, p. 13-14). Efficiency and prioritization go hand in hand as discursive themes with a moral character, concerning that we need research to create knowledge that could lead to economic value - and, as it seems to me, preferably in private business and industry (the Icelandic term is atvinnulifið).

While reading the Task Force report, I noticed the use of the term verkaskiptingappearing seven times - which refers to how the lines of study are divided between the 


\section{STJÓRNSÝSLA}

universities and that similar programs should not be on offer at many universities. It is noted that the history of the universities has determined some of their roles, with no clear logic as to who offers what. So the Task Force has made a simpler and clearer division of tasks between them („Einfaldari og skýrari verkaskipting háskóla“) as one of the key recommendations about the structure of the system. Among the main arguments is more efficiency in teaching and excellence (árangur) in research (MESC, 2009b, p. 10).

Table 1. Occurrences of selected terms in three reports on higher education in Iceland

\begin{tabular}{|c|c|c|c|c|}
\hline Term & $\begin{array}{l}\text { Group } \\
\text { (numbers refer } \\
\text { to Section 3.1) }\end{array}$ & $\begin{array}{c}\text { Expert Panel } \\
2009\end{array}$ & $\begin{array}{c}\text { Task Force } \\
2009\end{array}$ & $\begin{array}{c}\text { Simplifying } \\
2012\end{array}$ \\
\hline $\begin{array}{l}\text { Efficiency, efficient } \\
\text { Nýting (good use of money or human } \\
\text { capital) } \\
\text { Samlegð } \\
\text { Skilvirkni } \\
\text { Verkaskipting (division of tasks) }\end{array}$ & 1 & 11 & $\begin{array}{l}3 \\
6 \\
3 \\
7\end{array}$ & $\begin{array}{l}6 \\
1 \\
7 \\
2\end{array}$ \\
\hline $\begin{array}{l}\text { Prioritization, prioritize, priority } \\
\text { Focus } \\
\text { Forgangsröđun }\end{array}$ & 1 & $\begin{array}{l}19 \\
18\end{array}$ & 3 & 2 \\
\hline $\begin{array}{l}\text { Einföldun, einfaldur, einfalda } \\
\text { (simplification, simple, simplify) }\end{array}$ & 1 & $\begin{array}{c}\text { No corre- } \\
\text { sponding word }\end{array}$ & 7 & 14 \\
\hline $\begin{array}{l}\text { Innovation } \\
\text { Nýsköpun }\end{array}$ & 2 & 56 & 58 & 89 \\
\hline $\begin{array}{l}\text { Verðmætasköpun (creation of economic } \\
\text { value) }\end{array}$ & 2 & $\begin{array}{c}\text { No corre- } \\
\text { sponding word }\end{array}$ & 5 & 19 \\
\hline Governance & 3 & 10 & $\begin{array}{c}\text { No corre- } \\
\text { sponding word }\end{array}$ & $\begin{array}{c}\text { No corre- } \\
\text { sponding word }\end{array}$ \\
\hline Rekstrarform & 3 & $\begin{array}{c}\text { No corre- } \\
\text { sponding word }\end{array}$ & 10 & 3 \\
\hline $\begin{array}{l}\text { Private } \\
\text { Einka- }\end{array}$ & 3 & 32 & 4 & 1 \\
\hline $\begin{array}{l}\text { Public } \\
\text { Opinber }\end{array}$ & 3 & 47 & 42 & 30 \\
\hline $\begin{array}{l}\text { Excellence, excellent } \\
\text { Árangur } \\
\text { Öndvegis- }\end{array}$ & 4 & 11 & $\begin{array}{c}13 \\
0 \\
\end{array}$ & $\begin{array}{c}71 \\
1 \\
\end{array}$ \\
\hline $\begin{array}{l}\text { Quality } \\
\text { Gæði }\end{array}$ & 4 & 13 & 20 & 55 \\
\hline $\begin{array}{l}\text { Competitiveness, competitive, } \\
\text { competitively, competitive funding } \\
\text { Samkeppni, samkeppnissjóđir }\end{array}$ & 5 & 23 & 51 & 37 \\
\hline $\begin{array}{l}\text { Change } \\
\text { Breytingar }\end{array}$ & 6 & 11 & 27 & 13 \\
\hline $\begin{array}{l}\text { International } \\
\text { Alpjóđlegur }\end{array}$ & 7 & 26 & 25 & 15 \\
\hline $\begin{array}{l}\text { Mobility } \\
\text { Hreyfanleiki }\end{array}$ & 7 & 6 & 1 & 2 \\
\hline Exchange (of ideas or people) & 7 & 5 & $\begin{array}{c}\text { No corre- } \\
\text { sponding word }\end{array}$ & $\begin{array}{c}\text { No corre- } \\
\text { sponding word }\end{array}$ \\
\hline Academic freedom (akademískt frelsi) & 8 & 0 & 0 & 0 \\
\hline
\end{tabular}




\section{STJÓRNMÁL \\ STJÓRNSÝSLA}

\subsubsection{Innovation}

The number of occurrences of innovation is high, but that is only a small part of the story. Tying together research, science and innovation was what the Expert Panel was asked to do. The underlying assumption seems to be that the task of research and science is to serve business and industry. However, while the Expert Panel recommends "focus on innovation" as a key strategy (MESC, 2009a, p. 22), it does not propose that the only goal of research should be innovation in business and industry. Yet the recommendations for prioritization are narrow, emphasizing natural sciences and technology where three areas_- "geothermal sciences, life sciences, creative industries/ICT"- - are especially mentioned (MESC, 2009a, p. 22).

In relation to the reports' overt focus on innovation, there is an emphasis on veromatasköpun - I think most correctly translated as creating economic value in terms of material goods-in the Task Force report. Verðmætasköpun is a term with a moral dimension, which carries with it the conception that research should be useful, even in the short run. This is part of the efficiency discourse.

Innovation as a discursive theme is also related to demands for a connection between academia and business and industry. One of the section headings is "Perception of government by some of Iceland's "star" companies" where it is, among other things, argued that "it is clearly important for a government to have a good relationship with the private sector, and particularly "star" companies, during difficult economic times" (MESC, 2009a, p. 15). This is a good example of the size-matters pattern in the discourse.

\subsubsection{Governance and the private-public divide}

Governance is an important theme in the discourse of the reports. The term itself, governance, appears ten times in the Expert Panel report, not least in section headings. However, I think that within this theme the private-public divide is most important, given the high number of occurrences, 32 for private and 47 for public in the Expert Panel report and 42 for opinber (public) in the Task Force report. Under this theme we see a criticism to the effect that private universities and private bodies have less access to resources provided by public financing. In a somewhat moral sense, it is considered good if public universities or research institutes cooperate with bodies in the private sector; therefore it is recommended that "collaboration between the public and private sectors, although such collaboration is not required" (MESC, 2009a, p. 8) should be stimulated.

There are seven recommendations by the Expert Panel about governance. One of them is that the Science and Technology Policy Council "should always be chaired by the Prime Minister" (MESC, 2009a, p. 21). It is suggested that Rannís (i.e., The Icelandic Research Center) should be a support agency to the Council and placed under the prime ministry or even made into an independent agency (MESC, 2009a, p. 22). While I do not think that it is meant that the Prime Minister should decide upon how particular grants are determined, such political input sounds to me as a power-matters pattern, which I consider a close discursive relative of the size-matters pattern. 


\section{STJÓRNSÝSLA}

\subsubsection{Excellence and quality}

Because most of the time the terms excellence and quality (11 and 13 times respectively in the Expert Panel report) refer to one term in Icelandic, the word gadi, they are a pair in the discourse. The term gæði (20 times in the Task Force report) most often means quality, especially in combinations such as quality assurance, quality improvements, quality control, and quality of education. In a general discussion, I would probably translate the term excellence with a slightly stronger word than gæði, i.e. ágæti. In the discourse on research, it has also been used as öndvegis-, combined with, for instance, setur (i.e., öndvegissetur) to refer to a center of excellence. In the end I came to the conclusion that the often-used word arangur would also be somewhat equivalent to excellence.

The focus on excellence and quality indicates the ethical concerns which are also apparent in the Task Force report where it is suggested that the demands, placed upon universities in the 2006 legislation, should be enhanced and that they should increasingly assess teaching and learning (MESC, 2009b, p. 10). When accreditation took place in 2007-2008, the reporting was more concerned with governance and organization than with teaching and research. There seems to be a strong moral undertone in the discussion with regard to the need to assess and evaluate teaching and research.

\subsubsection{Competitiveness}

The noun competitiveness (samkeppni), the adjective competitive, and the adverb competitively are often used, as is also the phrase competitive funding (in Icelandic the noun is in the plural samkeppnissjodir), 23 times in the Expert Panel report and 51 times in the Task Force report. The Expert Panel complains that "competitive funding is too low (14\%) to allow for management of research and science in a dynamic and cost-efficient way" and that "the size of competitive grants is in general too small to provide the support required for cutting edge new ideas". It goes on to argue that "increasing the levels of competitive funding is one way to increase the efficiency and effectiveness of public funding ..." (MESC, 2009a, p. 14).

The Expert Panel recommends that the block funding should be internally distributed in competitive ways "and only the best proposals should be funded in current circumstances" (MESC, 2009a, p. 14). If this would be taken to the extreme, no researcher would have $40 \%$ of the time allocated for research as now in the state universities—or, more likely, that more of the research time than now would be dependent upon the quantity of certain publications. While I do not think that the $40 \%$ allocated research time should be sacred, there is no caution about any type of consequence of such a fundamental change.

\subsubsection{Change}

I looked at how often change is mentioned; 11 times in the Expert Panel report, and 27 times in the Task Force Report. In the Task Force report, I looked at the verb breyta as well as the noun breytingar and the adjective breyttur. Often this is simply used as descriptive of how the legislation or other conditions have changed. I also studied the proposals 
of the committees to investigate how they understand change. The Expert Panel suggests "five key messages to Icelandic policy makers":

"Maintain investments in education at all levels"
"Reshape the education and research landscape"
"Focus on innovation"
"Reform and strengthen governance structures and systems"
"Unite support for short-term change and implement it quickly".

(MESC, 2009a, p. 18, italics removed, but original as a list)

In brief, these key messages and their explanations suggest that it is relatively easy to change: "Reshape", "implement it quickly", etc.

The Task Force has three main recommendations about change: To simplify and coordinate the institutional structure of the university system of Iceland with the intention of shaping more powerful units and facilitating cooperation between them; that universities enjoy equality in support and funding from the state and official agencies; and that science and research should be supported in more effective ways to create more value and jobs (MESC, 2009b, p. 4). In this way the Task Force takes the moral stance that the private universities or other such bodies are perhaps discriminated against by less access to funding. The Task Force also subscribes to the size argument.

In sum, the report authors present the view that it is easy to change, and they suggest using size and power as measures to bring about change in order to enhance efficiency.

\subsubsection{International comparison and cooperation}

The discussion of international connections is less prominent in the foci of the reports than the efficiency theme. Nevertheless, international and the Icelandic equivalent, alpjó $\delta$ legur, appear 25 and 26 times in the relevant reports, but most of the time in discussion of the necessity to be able to compare with other countries or to cooperate.

Mobility, mentioned six times by the Expert Panel, and exchange of ideas or people, mentioned five times in the same report, are both recommended in the context that learning from others is useful. The Icelandic equivalent for mobility, hreyfanleiki, is referred to only once by the Task Force, and I did not find any equivalent for exchange. I am not sure if and how to interpret these differences. But all things considered, I think the theme international in terms of comparison and cooperation, given also the mention of mobility and exchange, is an important theme in the discourse.

\subsubsection{Academic freedom-a non-present theme}

Finally, I searched for academic freedom as a term. It is not used in the reports, and it seems to me that the term "academic" is only used once-in the combination "academic research with industrial application" (MESC, 2009a, p. 16). I conclude from this that the authors of the reports do not think that even mentioning academic freedom may help in legitimating their claims about quality, innovation, and so forth. It is easy also to un- 
derstand this assertion in connection with the focus on innovation and the demand that research must be useful for business and industry in the relatively short run. Here the authors portray a contradiction between "academic" and "application"; academic freedom is not only irrelevant - but possibly a hindrance to application in business and industry.

\subsubsection{Patterns of legitimation}

Besides the discursive themes, there are three underlying patterns of legitimation: the impact of the crisis, a moral stance, and size and power matter.

In the first place, the reports were indeed meant to provide ideas as to how to respond to the financial trouble of the state after the bank system collapse in October 2008 (MESC, 2009c). This alone lends legitimacy to their briefing, almost regardless of what would be said. But at the same time, it seems to me that both the Expert Panel and the Task Force treat issues and problems in Icelandic higher education somewhat independently from the crisis. For instance, these texts taste as if the necessary improvements are not related to the crisis, and suggest that the system was not efficient prior to the crisis. This tone appears almost at the beginning of the Expert Panel report: "Higher education in Iceland has grown and diversified more quickly and more recently than [in] almost any other OECD country, and circumstances dictate that Iceland must now adapt its system more quickly than others as well" (MESC, 2009a, p. 3). Certainly the reports present a contradictory stance about the collapse and crisis, and the crisis may indeed be an excuse to address what the report authors conceive of as the inefficiency of the system.

A subpattern of the crisis pattern in this discourse is a branch of the international business masculinity discourse (e.g., Pétursdóttir, 2011). ${ }^{5}$ We can, for instance, see this in the words "increased outreach and status in international competition" (MESC, 2009b, p. 16) and the notable phrase "star" companies. I consider this a sub-pattern of the crisis pattern because it may have been such masculinity that contributed to the bank collaps in 2008 (see Einarsdóttir \& Pétursdóttir, 2010).

Secondly, I argue that there is a the moral undertone of the reports, at times rather obvious in the language and almost all the time underlying in a "something needs to be improved"-attitude. But I think the authors of the reports are not much aware of this. The foci on efficiency, prioritization, innovation, competitiveness, and so forth are so unquestioned, and presented as inevitable. The moral stance is intervowen with efficiency claims.

Thirdly, there is the pattern that university size matters and that they need to be more powerful. The Task Force argues that larger institutions can be stronger in the international field (MESC, 2009b, p. 11). The focus on areas of strengths and the possibilities to steer the system "efficiently" is an important theme that relates to the topic "size matters". The phrase "promising areas" is one of the indications of the belief that change is easy, and that it is possible to identify such areas and make them larger. 
Excellence, Innovation and Academic

Freedom in University Policy in Iceland

Ingólfur Ásgeir Jóhannesson
STJÓRNMÁL

STJÓRNSÝSLA

\subsection{Discursive themes in the $\mathbf{2 0 1 2}$ report}

The analysis of the 2012 report, called the Simplifying report, dealt with whether and how the underlying patterns of legitimation in the 2009 reports remained intact. Thus, this section starts with reporting what remains intact, continues with potential differences in the recurrent themes and concludes with what I consider as new in the patterns of legitimation.

\subsubsection{A moral stance and the size-matters patterns remain intact}

In the very first sentence of the Simplifying report, the tone seems to be set by emphasizing fragmentation and inefficiency of the science and innovation system, and it is stated that such a conclusion is derived from earlier reports. It is also pointed out that earlier reports have stressed the arguments for the merging of the universities (Starfshópur, 2012, p. 8). The normative tone of the earlier reports and the size-matters pattern are easily recognized in this text and in the recommendations, where a number of mergers is suggested. However, the Simplifying report of 2012 may be more practical in its recommendations than the 2009 reports, not because that all suggested mergers are viable, but because they are more specific and seem in that regard easier to evaluate. These recommendations indicate to me that the size and power-matters pattern is even stronger in the 2012 Simplifying report than in the 2009 reports; the proposals for change adhere to the idea that larger and more powerful institutions or units of cooperation (such as the suggested National Center for Doctoral Studies) are the way to go.

The crisis after the collapse in 2008 is almost non-existent in the Simplifying report. It is only mentioned twice, once in combination with the Expert Panel report from 2009 and once in conjunction with the positive sign that since the bank system collapse 150 jobs had been created in innovation firms (sprotafyrirtæki) related to research projects of the University of Iceland professors and students (Starfshópur, 2012, p. 15).

All in all, there is very little difference in the discourse of these reports. Below I discuss some of the variations that clearly show that the legitimating patterns of the 2009 reports are at least somewhat durable as principles of legitimation.

\subsubsection{Recurrent discursive themes-or with new twists}

In this section, it is examined if or how the themes identified in the 2009 reportseficiency and prioritization; innovation; governance and the private-public divide; excellence and quality; competitiveness; change; and international comparison and cooperation, as well as the non-present academic freedom-are recurrent in the 2012 Simplifying report. Each of them is evaluated from the perspective of how often the terms are mentioned and whether the tone remains. It is also considered whether something does not exist in the Simplifying report or what might have been added or further emphasized.

The simplete counting of words (see Table 1) that correspond to efficiency revealed no particular difference, and the very name of the report, Einföldun (i.e., Simplification) 
suggests, there is much focus on efficiency. What I found most interesting concerning efficiency are recommendations to merge universities (even from seven into two), research institutions, and in some cases universities and research institutions. The report suggests merging five of the thirteen independent research institutions with universities and that four research institutes should be merged into one. Here we see the argument that size matters in full force.

Arguments concerning the connection between education and economy continue, and even become stronger than in 2009 . We see this most obviously by counting the term innovation and its Icelandic counterpart, nýsköpun. This term appears even more often in the Simplifying report, or 89 times compared to 56 and 58 times of the 2009 reports. I also counted how often verðmætasköpun appears in the reports in Icelandic: In the 2009 Task Force report it appears five times and 19 times in the 2012 Simplifying report.

Further on the theme of innovation, I believe that the Simplifying report binds research, science, and innovation even more strongly together in the search for more economic growth. These three terms, while not used interchangeably, are linked in such a way that research and science have now, somehow, achieved the ultimate goal of innovation and the creation of value in the material sense of creating goods.

Concerning governance and the private-public divide, there is a continuing trend of emphasizing the divide. While the word rekstrarform, referring to the formal ownership of each university, only appears three times in the Simplifying report, compared to ten times in the 2009 Task Force report, there are recurrent worries about the different conditions private and public universities work under.

Excellence and quality continue to be strong themes. Indeed the term árangur is mentioned 71 times in the Simplifying report compared to 13 times in each of the 2009 reports, and geodi occurs 55 times compared to 13 and 20 times in each of the 2009 reports. While gæði and quality are probably almost identical, árangur does not necessarily mean exactly the same as excellence. It also means being accountable for the excellence that is sought after, for instance in using accountable schemes for funding, the importance of which is highlighted in the report. The 2012 report discusses current practices in Iceland, and provides examples from other countries to demonstrate how it might be possible to further measure the efficient use of funds. Using information systems to gain better oversight is suggested (Starfshópur, 2012, p. 24). In this discussion, the moral stance is just as apparent as in the 2009 reports. Using the term gæði more often also relates to the power discourse of funding the "best [research] teams and/or the best individuals" (Starfshópur, 2012, p. 18).

This brings us to the theme of competitiveness. While the word samkeppni appears 37 times in the Simplifying report compared to 51 times in the 2009 Task Force report, there is also more emphasis in the Simplifying report on competition over the funds, such as between universities, faculties, or individuals.

Concerning the theme of change, a term that appeared 11 and 27 times in each of the 2009 reports, it appears 13 times in the Simplifying report. I think that einfoldun (simplification) has replaced change; now there is basically one type of change that is valid, i.e. 


\section{STJÓRNMÁL

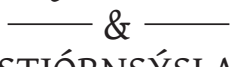

simplifying, creating fewer and larger and more powerful institutions, whether universities or other research bodies. All of them should be accountable, and they should focus on innovation.

In terms of international comparison, I found some moral use of the concept that Iceland is not comparing well enough to other countries. There is also an emphasis on international cooperation, not least in research projects, which I consider an example of the size-matters pattern.

Academic freedom continues to be almost unmentioned. Academic freedom is referred to once in the Simplifying report, in Part B, in the context that the European University Association had performed a study on the independence of state universities in Europe where academic independence was, among other things, under consideration (Starfshópur, 2012, p. 46). We could also interpret more monitoring and reporting of publications through information systems to be a potential threat to academic freedom.

\subsubsection{Conclusive notes on what is possibly new in the patterns of legitimation}

There is not much "new" in the patterns of legitimation. The underlying moral stance and the size-and-power matter pattern continue. Ignoring the importance of academic freedom continues. These patterns may have become durable enough to be called the principles of the discourse. And patterns of legitimation which might be considered new, most importantly reorganization and innovation, are not entirely new, however. Suggestions to reorganize the system are legitimated by merely saying that it is important to do so, although sometimes such assertions are also interwoven with arguments premised on size and power. Reorganization becomes a particular pattern under the rubric of "einföldun", where reorganization, size, and power are intertwined.

Another such new pattern, identified in the terms innovation and verðmætasköpun, is also definitely a thread from the 2009 Expert Panel report, but with an even stronger focus on the economic argument for emphasizing higher education. This is done by further linking together research, science, and innovation with the goal of boosting economic growth. Through this continuing focus on innovation we see to undertone that it is relatively easy to define what is good research or even quality research-because what makes research good is its usefulness for business and industry.

\section{Historical conjuncture? Discussion and some conclusions}

I have so far examined how selected reports deal with issues of efficiency and competitiveness and how they use concepts of quality and excellence. Throughout the examination I have simultaneously counted the use of the above words as well as around 20 other terms in English or Icelandic. This study indicates an underlying moral discourse concerning efficiency and the use of funds. This should not have been surprising in the historical conjuncture of the neo-liberal discourse of accountability and a recurrent masculinity discourse. Below I consider some of tensions and possible consequences of the discursive themes, patterns and principles that have been observed in the reports under scrutiny. 


\subsection{Very little sense of history}

What surprised me was that the economic crisis following the collapse of the bank system was infrequently referred to. Nevertheless, the crisis was a background for the kind of emphasis and reorganization that is recommended, as well as enhancing the morality supporting the notion that funds might not be used wisely.

Most of the recommendations are made to look inevitable, sometimes in bulleted or numbered lists. They are argued rather forcefully—but in a relatively simple manner and do not seem to be based on experiences of university developments or what might be learned from earlier mergers of various institutions. For instance, the 2012 Simplifying report recommends mergers of universities and research institutions without using what might be learned from, for instance, the merger of the Agricultural Research Institute with the Agricultural University of Iceland in 2005.

The most surprising omission in the reports relates to the Bologna Process (Geirsdóttir \& Jóhannesson, 2010). If we contrast this to two themes in the Bologna Process, mobility and quality, the omission in the 2009 and 2012 reports is consistent with how seldom mobility and transferability are mentioned in the reports, but surprisingly not consistent with the focus on quality and efficiency where one might think that the induction of the Bologna process into the universities would offer a practical platform for faculty and staff to relate to the reports's recommendations.

In 2007-2008 all university programs were accredited without much criticism, documents accrediting the universities released, and photo opportunities created for the university officials and the minister of education, science, and culture. Nevertheless, only two years later, the 2009 reports claim that reform of the university system is needed, even sorely so. While I cannot state that the accreditation process was perfect in pointing out the strengths and weaknesses, I find it strange that there is such criticism on the universities in 2009 and 2012 without pointing out what may have gone wrong in the accreditation process.

These silences are contradictory to the efficiency agendas. I am surprised that discussing an example of a merger of universities or a university and a research institution is not supposed to be useful. I am also surprised that efficiency and quality control exercises, such as the Bologna Process and the accreditation, are not considered worthwhile to discuss.

\subsection{The emphasis on innovation-in contrast with academic freedom?}

There is no absolute way to assess the consequences which demands for innovation placed upon the universities might have for academic freedom. However, through my investigation, I feel confident to conclude that the rather narrow focus on quality and excellence is not tolerant towards research which is not geared to the creation of economic value or seen as immediately or obviously useful. Furthermore, there is the tendency to define quality and excellence narrowly_- "excellent research [is] based upon a particular system of indicators", as the Maarten Simons and Jan Masschelein (2007, p. 157) phrase it. They also state: "Being obsessed with quality and excellence is the only 


\section{STJÓRNMÁL $\&$ \\ STJÓRNSÝSLA}

way to guarantee our [the universities'] survival"' (Simons and Masschelein, 2007, p. 141). The new quality assurance system for Icelandic universities (see The Quality Board for Icelandic Higher Education, 2011) is now being implemented. No university faculty can or will be allowed to boycott the quality assurance system or the Bologna Process, so these become influential in the sense that dealing with takes time for faculties and faculty members.

The three reports I analyzed convey the undertone that it is relatively simple to define good research, or excellent research, and what makes it excellent is how good it is for business and industry, even in the short term. The reports also tie research and science into a bundle with the conception of innovation. The tendency to tie together research and innovation in such a way has also been observed by Geert Biesta and colleagues from six European countries (2008). They conclude that "the managerial attitude in search of innovation strategies ..." as well as the managerial viewpoint in general highlights "efficient and effective production of research, teaching and innovation ..." and that this dismantles institutions and restructures organizational units (Biesta et al., 2009 , p. 250). They also point out that the enterprise of reorganizing universities and research institutions, in favor of research in the service of business and industry, is made to appear inevitable.

So what might this have to do with academic freedom? I believe that the term "unreasonable interference" in the basic definition, cited at the beginning of the article, is a key concept in understanding. I am uncertain as to whether the two 2009 reports and the 2012 Simplifying report, or the quality assurance system, or many other initiatives referred to, would count as "reasonable interference". These initiatives tend to increase workload, they refocus efforts from research and teaching to administration, they prioritize values, they sound as if there is moral failure somewhere that we are all responsible for. The reports do not bother to discuss what academic freedom might be, or, for example, what the proposals of reorganizing institutions might do to any other sphere of activity than innovation and the creation of economic value. And, "in the name of excellence ... an entrepreneurial ethos " is required of the universities' staff (Masschelein and Simons, 2009, p. 237).

I believe that the discourse, which the two 2009 reports and the 2012 Simplifying report are part of, impacts academic freedom because the types of scholarship not aimed at serving the relatively narrow needs of business and industry seem to be less favored. This is not a direct consequence of the reports themselves but also relates to the different composition of the universities and their course offerings, including the fact that graduate programs are now available in a widespread variety of academic fields. Norman Fairclough and Ruth Wodak (2008) connect this to a contradiction between Humboldtian principles of morally and intellectually independent institutions and the social demands that universities should work in public service. They point out that universities are struggling with these two poles as if they are compatible rather than in contradiction to each other. The reports are of this character: they appear to contain unquestionable truths, but do not discuss the internal contradictions. 


\subsection{Masculinity discourse}

The language in the reports is mostly gender-neutral although they use the generic male nouns visindamenn (scientists) or rannsakendur (researchers), which in ordinary Icelandic are meant to refer to both men and women. I am not comfortable with the silence about the situation of the people who perform research, science, and innovation; reading the reports gives no sense of the men and women who actually work in higher education and research institutions.

Delving beneath the surface, the discourse of the reports is firmly masculinized. First of all, there is good reason to be suspicious of arguments concerning that larger institutions are better, indeed for both men and women professors and researchers, although I believe that such a discourse tends to favor men. And I think there is reason to be even more deeply concerned with how the emphasis on competition, "intelligent prioritization", and "star" companies is closely related to and must be viewed in context with the creation of international business masculinity (see Pétursdóttir, 2011).

In this context, we could call this the masculinity of acquiring funds to hire people to work for you; something that goes against the image of the lone researcher, for instance contemplating how to interpret the latest best-seller novel in light of literary theory or digging into the historical archives for forgotten knowledge. For someone like myself as originally a historian this consideration takes me right to the actual choices that I must make as an academic researcher: whether to work alone or work with others, even to take a leadership role to acquire funds and hire people. This discourse of large funds and research teams that one could become the head of to perform research is seductive to us in the world of academia. Of course, the "lone researcher" is not a non-masculine identity, but refers to a different masculinity, less favored in the current discourse. Innovation, through its connection with entrepreneurship, also symbolizes to me a type of masculinity, that of the inventor of useful tools and equipment.

It is no news that discourses of how to behave in the university describe masculine ways where women are "guests" (O’Connor, 2011; Van den Brink and Benschop, 2011). The university is a heroic place where publications count as ever, as they indeed always did. With the addition of entrepreneurship, competitiveness, and a focus on large entities it is not likely that the discourse and organizational structures of the universities is going to sway away from masculinity any time soon.

\section{Final words}

Biesta et al. (2009) suggest that we need a discussion about what the universities have to offer, not only for business and industry but for anyone, and Guðmundur Heiðar Frímannsson (2012, p. 265), points out that it is "inevitable that some of the teaching and research in theoretical disciplines at universities is not useful or socially relevant in any significant sense ...". While agreeing with Biesta and colleagues and Guðmundur Heiðar Frímannsson, I think we need not necessarily fully abandon the discourse of competitiveness and excellence and quality. We should not, however, think of spending all our time on such efforts, but should simultaneously engage with questions about the 


\section{STJÓRNMÁL $\&$ STJÓRNSÝSLA}

public role and societal responsibilities of the universities. This is not to go backwards to some neutral position of the university as an ivory tower. As two of Biesta's co-authors, in another article, also warn that we would never be going back the old days of "truthtelling" (Simons and Masschelein, 2007). The universities must engage in discussions about their role - and that is why I bother.

That there is research on the public role of the universities, for instance the project Samfélagslegt hlutverk háskóla (acronymed as SamHá), is important (e.g., Dorsteinsson, Kristinsson \& Sigursteinsdóttir, 2012). We need to examine what the universities' faculty members think about the social, cultural, and political roles and responsibilities of the universities. We need to discuss the consequences of the divide between the focus on academic freedom and a neutral position - in a traditional sense of the notion of sitting in the ivory tower-and service to business and industry through an over-emphasis on innovation. We need to discuss, as our above-cited colleagues in other European countries suggest (Biesta et al., 2009) and in Iceland (e.g., Jónasson, 2008), in which other ways the universities can develop as vibrant units in cooperation with all sectors of society.

\section{Notes}

1 Most of the information in this section derives from two of the reports under analysis (Ministry of Education, Science, and Culture, 2009; Starfshópur Vísinda- og tækninefndar VTR, 2012) and the websites of the universities. In the article, I talk about all higher education institutions as "universities", although many of them, other than the University of Iceland, should be called colleges rather than universities.

2 The term "einföldun" in the title of the report is a noun that means simplification or simplifying. I use the direct translation when translating the title, but in the analysis I acknowledge the connotation that the noun "einföldun" and the verb "einfalda" have to notions of efficiency.

3 Briefly after the analysis was completed, the Office of the Prime Minister, in cooperation with The Science and Technology Policy Council and Rannís, released a new version of the Simplifying report, entitle Ný sýn_breytingar á vísinda- og nýsköpunarkerfinu (New vision_Changes in the science and innovation system) (Office of the Prime Minister, 2012). While this report has not been analyzed in the same manner, and terms not counted, a reading of it indicates that it is in the same vein as the earlier reports.

4 All translations from the Task Force report 2009 and the Simplifying report 2012 are mine. I use US spelling in the article. The Expert Panel report, for the most part, not totally consistent, used UK spelling; I changed citations to US spelling to make them consistent.

5 The most common Icelandic term for international business masculinity has been útrásarkarlmennska that would translate as outreach masculinity. Many authors, for example Guðbjört Guðjónsdóttir \& Júlíana Magnúsdóttir (2011), use Viking masculinity simultaneously with útrásarkarlmennska, and Janet Elise Johnson (2011) names the phenomonon Viking neo-masculinity.

\section{References}

Auglýsing um útgáfu viðmiða um æðri menntun og prófgráður no530/2011 [Advert about the publication of a National Qualification Framework for higher education].

Biesta, Geert; Kwiek, Marek; Lock, Graheme; Martin, Hermínio; Masschelein, Jan; Papatsibia, Vassiliki; Simons, Maarten \& Zgaga, Pavel. (2009). What Is the Public Role of the University? A Proposal for a Public Research Agenda. European Educational Research Journal, 8 (2), 249-254. Retrieved 5 January 2013 from www.wwwords.eu/EERJ. 
Bourdieu, Pierre. (1988). Homo Academicus. Stanford: Stanford University Press.

Einarsdóttir, Porgerður \& Pétursdóttir, Gyða Margrét. (2010). Greining á skýrslu rannsóknarnefndar Alpingis frá kynjafræðilegu sjónarhorni [fylgiskjöl II] [Analysis of Parliament's inquiry (into the bank collapse), from a gender studies perspective] In Atli Gíslason (ed.), Skýrsla pingmannanefndar til að fjalla um skýrslu rannsóknarnefndar Alpingis [Parliamentary committee report on Parliament's inquiry] (pp. 209-267). Reykjavík: Althingi.

Encyclopædia Britannica. (n.d.). Academic Freedom. Article. Retrieved 30 August 2012 from http:// www.britannica.com/EBchecked/topic/2591/academic-freedom.

Fairclough, Norman and Wodak, Ruth. (2008). The Bologna process and the knowledge-based economy: A critical discourse analysis approach. In Bob Jessop, Norman Fairclough, and Ruth Wodak (eds.), Education and the knowledge-based economy in Europe (pp. 199-125). Rotterdam: Sense.

Frímannsson, Guðmundur Heiðar. (2012). Akademískt frelsi [Academic freedom]. Stjórnmál \& stjórnsýsla, 8(2), pp. 265-280.

Foucault, Michel. (1979a). Governmentality. Ideology and Consciousness, 6, 5-21.

Foucault, Michel. (1979b). What is an author? In J. V. Harari (Ed.), Textual strategies: Perspectives in poststructural criticism (pp. 141-160). Ithaca, NY: Cornell University Press. [Available in Icelandic translation, in Foucault, Michel (2005), Alsci, vald og pekking (pp. 69-94). Bókmenntafræðistofnun Háskóla Íslands: Reykjavík.

Geirsdóttir, Guðrún \& Jóhannesson, Ingólfur Ásgeir. (2010). Bolognaferlið og íslenskir háskólar: Inngangur [The Bologna Process and Icelandic universities: Introduction]. Uppeldi og menntun [Icelandic Journal of Education], 19(1-2), 181-185.

Guðjónsdóttir, Guðbjört \& Magnúsdóttir, Júlíana. (2011). Ingólfur Arnarson, Björgólfur Thor og Ólafur bóndi á Porvaldseyri. Karlmennska, kynjakerfi og pjóðernissjálfsmynd eftir efnahagshrun [Masculinity, patriarchy, and national identity after the economic collapse, using as examples Ingólfur Arnarson (officially Iceland's first settler), Björgólfur Thor (an international Icelandic business man), and Ólafur (enterpreneurial farmer in South Iceland)]. In Silja Bára Ómarsdóttir (ed.), Rannsóknir í félagsvísindum XII. Stjórnmálafreơideild. Erindi flutt á rádstefnu i október 2011 [Research in the Social Sciences. Conference Proceedings] (pp. 45-53). Reykjavík: Félagsvísindastofnun Háskóla Íslands.

Guðmundsson, Magnús. (2011). Rannsóknaháskólinn 1990-2011 [The research university]. In Gunnar Karlsson, Aldarsaga Háskóla Íslands 1911-2011 [University of Iceland one century old] (pp. 553-779). Reykjavík: The University of Iceland Press.

Johnson, Janet Elise. (2011, August 25). Can women clean up Iceland's man-made mess? Why feminist political scientists must theorize corruption. Prepared for the 2011 meeting of the European Consortium of Political Research, Reykjavik, Iceland. Retrieved 24 August 2012 from http://www.ecprnet.eu/MyECPR/proposals/reykjavik/uploads/papers/924.pdf.

Jóhannesson, Ingólfur Ásgeir. (2006). Leitað að mótsögnum. Um verklag við orðræðugreiningu [Finding contradictions. How to analyse discourse]. In Rannveig Traustadóttir (Ed.), Fötlun. Hugmyndir og aðferdir á nýju fraðasvið̇i [Disability. Ideas and methods for a new research area] (pp. 178-195). Reykjavík: Háskólaútgáfan [University of Iceland Press].

Jóhannesson, Ingólfur Ásgeir. (2010). The politics of historical discourse analysis: A qualitative research method? Discourse: Studies in the cultural politics of education, 31(2), 251-264.

Jónasson, Jón Torfi. (2008). Inventing Tomorrow's University. Who is to take the lead? Bologna: Bononia University Press.

Lög um háskóla [Higher Education Institution Act] no 63/2006.

Masschelein, Jan \& Simons, Maarten. (2009). From active citizenship to world citizenship: A proposal for a world university. European Educational Research Journal, 8(2), 236-248.

Ministry of Education, Science, and Culture (MESC). (2009a). Education, Research and Innovation Policy. A new direction for Iceland. Reykjavík: Author. [Expert Panel report.]

Ministry of Education, Science, and Culture (MESC). (2009b). Verkefnastjórn vísinda og háskólamála. 


\section{STJÓRNMÁL $\&$ STJÓRNSÝSLA}

Skilagrein [Task Force of Science and University. Report Overview]. Reykjavík: Author. [Task Force report.]

Ministry of Education, Science, and Culture (MESC). (2009c). Nýjar úttektir á háskóla- og vísindakerfinu. Stefna i menntun, vísindum og nýsköpun: Ný leid fyrir Ísland [New reports on the higher education and research system. Education, Research and Innovation Policy. A new direction for Iceland]. Reykjavík: Author. [Press Release.]

Ministry of Education, Science, and Culture. (2009d). Adgerdir i háskóla- og vísindamálum. Skilagrein rýnibóps menntamálarádherra [Actions in higher education and reearch issues. From the focus group appointed by the minister of education, science, and culture]. Reykjavík: Author. [The Follow-up report.]

O' Connor Pat. (2011). Is senior management in Irish universities male-dominated? What are the implications? Irish Journal of Sociology, 18(1), 1-21.

Office of the Prime Minister. (2012). Ný sýn—breytingar á vísinda- og nýsköpunarkerfinu [New visionChanges in the science and innovation system]. Reykjavík: Author.

Pétursdóttir, Gyða Margrét. (2011). Sköpun alpjóðlegrar viðskiptakarlmennsku: Íslenskt tilvik [The creation of international business masculinity: An Icelandic case]. Í Silja Bára Ómarsdóttir (ritstjóri), Rannsóknir i félagsvísindum XII. Stjórnmálafradideild. Erindi flutt á rádstefnu i október 2011 [Research in the Social Sciences. Conference Proceedings] (pp. 60-68). Reykjavík: Félagsvísindastofnun Háskóla Íslands.

Presidents of Icelandic Universities. (2005). Yfirlýsing um forsendur og frelsi báskóla [Statement regarding academic principles and academic freedom]. Retrieved 5 October 2012 from http:/ /www.bifrost.is/ islenska/um-haskolann/frettir/nr/22768.

Prime Minister's Office \& Science and Technology Policy Council. (2010). Building on solid foundations. Science and technology policy for Iceland 2010-2012 [Official English edition]. Reykjavík: Author.

Sharp, Liz \& Richardson, Tim. (2001). Reflections on Foucauldian discourse analysis in planning and environmental policy research. Journal of Environmental Policy \& Planning, 3(3), 193-209.

Simons, Maarten \& Masschelein, Jan. (2007). Only love for the truth can save us: Truth-telling at the (world)university? In Michael A. Peters and Tina Besley (Eds.), Why Foucault?: New Directions in Educational Research (pp. 141-161). New York: Peter Lang.

Skúlason, Páll. (2008). Menning og markaðshyggja [Culture and the belief in the market as a driving force]. Skirnir, 182 (spring), 5-40.

Starfshópur Vísinda- og tækninefndar VTR [Working group of the science and technology committee of the Science and Technology Policy Council]. (2012). Einföldun á visinda- og nýsköpunarkerfinu. Skýrsla. Drög [Simplifying the research and innovation system. Draft report]. Reykjavík: VTR. [The Simplifying report.]

Statistics Iceland. (2012). Students by level, type of study, degree, narrow field of education and sex 1997-2011. Education-Universities. Retrieved 24 August 2012 from http://www.hagstofa.is/Hagtolur/Skolamal/Haskolar.

Stefánsdóttir, Steinunn. (2010). Fækkun háskóla blasir við [It is obvious to decrease the number of universities. Fréttabladid, May 19, p. 14

The Quality Board for Icelandic higher education. (2011). Quality enhancement bandbook for Icelandic bigher education. Reykjavík: Rannís. Retrieved 30 August from http://rannis.is/files/Handbook_ complete_1558767620.pdf.

University of Iceland. (2006). Stefna 2006-2011 [Policy 2006-2011]. Retrieved 19 August 2012 from http://www.hi.is/adalvefur/stefna_2006_201

University of Iceland. (No date). [Home Page.] Retrieved 5 August 2009 from http://www.hi.is.

Van den Brink, Marieke and Benschop, Yvonne. (2011). Gender practices in the construction of academic excellence: Sheep with five legs. Organization, 19(4), 507-524.

porsteinsson, Trausti; Kristinsson, Sigurður \& Sigursteinsdóttir, Hjördís. (2012). Samfélagslegt hlutverk háskóla [The public role of universities]. Stjórnmál \& stjórnsýsla, 8(2), pp. 281-302. 